\title{
Hepatitis B: Knowledge, Vaccine Situation and Seroconversion of Dentistry Students of a Public University
}

\author{
Marina Sena Lopes da Silva Sacchetto ${ }^{1,}$, , Simone Souza Lobão Veras Barros ${ }^{1}$, Thaís de Alencar \\ Araripe ${ }^{1}$, Aryvelto Miranda Silva ${ }^{1}$, Symonara Karina Medeiros Faustino ${ }^{2}$, José Mário Nunes \\ da Silva ${ }^{3}$ \\ ${ }_{2}^{1}$ Department of Pathology and Clinical Dentistry (DPCO), Federal University of Piaui, Teresina, Brazil \\ 2 Department of Pharmacy, Differential Integral Faculty (FACID), Teresina, Brazil \\ ${ }^{3}$ Department of Science and Health, Federal University of Piaui, Teresina, Brazil \\ ${ }^{*}$ Corresponding author: Marina Sena Lopes da Silva Sacchetto, Federal University of Piaui, Teresina, Brazil. Tel: +86-99070207, Fax:+86-32225461, E-mail:marinaslopes@yahoo.com.br
}

Received: July 18, 2013; Revised: September 02, 2013; Accepted: September 14, 2013

\begin{abstract}
Background: Viral hepatitis B (VHB) is an occupational risk for dentists. It is necessary that dental students start clinical practice immunized with the vaccine, response monitored and informed about the means of transmission of the disease. Rarely, there are studies which evaluate concomitantly knowledge of these academics and their vaccine situation.

Objectives: To evaluate the knowledge about Hepatitis B, the vaccine situation and the immunization status of dental students and to investigate the probable correlation between the status of immunization, vaccination membership and adherence to the test of seroconversion and associated factors.

Patients and Methods: 189 students from the dentistry course at the Federal University of Piaui (UFPI) who attended from the 3rd to 9th period were invited to participate in the research. Their knowledge about $\mathrm{HBV}$, attitude regarding protection and their vaccine situation were assessed through a self-administered form. Antibodies against surface antigens of Hepatitis B virus (Anti-HBs) and against the antigens of the virus nucleous of Hepatitis B (Anti-HBc total) were measured qualitatively using the enzyme-linked immunosorbent assay (ELISA).

Results: Of the 179 students surveyed, 58.1\% knew about the degree of virulence of the Hepatitis B virus (HBV). As to the means of transmission, $98.3 \%$ considered blood transmission, $82.6 \%$ plates and cutlery, $15.6 \%$ cough and $12.3 \%$ vertical transmission. Most students (87.4\%) knew that they should take 3 doses of the vaccine and $62.2 \%$ completed the immunization schedule. A minority of students (48.6\%) knew the about the Anti-HBs test and 5.6\% took the test. Among the students who reported having taken three doses of the vaccine, $12.5 \%$ were not seroconverted. There was no significant correlation between the variables.

Conclusions: Dental academics were unsure about the means of infection and prevention against HBV. Many of them had not completed the immunization scheme and did not have the test of seroconversion. The serological analysis revealed unprotection, even after students completed the vaccination schedule.
\end{abstract}

Keywords: Immunization Schedule; Hepatitis B; Antibodies; Occupational Accidents

\section{Background}

Viral hepatitis B is one of the most serious public health problems worldwide (1). There are more than two billion people infected in the world, of whom about 400 million are chronic carriers (2) and approximately 1 million people die annually because of the disease (3).

The transmission of the hepatitis B virus is by the parenteral route, and above all, it is transmitted sexually, being considered a sexually transmitted disease (4). Most people infected do not develop active liver disease, however, persistent infection can cause cirrhosis, liver failure or hepatocellular carcinoma (5). Liver transplant is the only hope for many patients with terminal liver diseases resulting from the $\mathrm{HBV}(6)$ and this represents a high cost to public health (5).

Surgeon-dentists are at increased risk of being infected by $\operatorname{HBV}(7,8)$. The main methods of contamination include needle punctures or exposure to blood and other body fluids (9). These professionals are at up to ten times greater risk of acquiring Hepatitis B than an ordinary citizen (10). To prevent blood transmission of infection, it is recommended that health care professionals receive immunization against the disease (11) and use personal protective equipment (PPE) (12).

Vaccination represents the main instrument to prevent HBV infection $(1,13)$. Immunization should be carried out

Implication for health policy/practice/research/medical education:

Aiming to reduce the risk of contamination by hepatitis B among dental students, greater adherence to preventive measures is recommended.

Copyright @ 2013, KowsarCorp.; Published by Kowsar. This is an Open Access article distributed under the terms of the Creative Commons Attribution License(http:/ creativecommons.org/licenses/by/3.0), which permits unrestricted use, distribution, and reproduction in any medium, provided the original work is properly cited. 
in three doses, with a month interval between the first and second dose and of six months between the first and the third dose, in order to stimulate the production of antibodies anti-HBs (4).

Although efforts have been made to vaccinate healthcare workers in Brazil, many do not vaccinate or do not complete the vaccination schedule (11). In addition, about $10 \%$ of these individuals do not produce sufficient antiHBS after receiving the vaccination schedule $(3,14,15)$ and therefore do not become protected. Thus, they must do the post-vaccination test until three months after the last dose of the vaccine (3).

The awareness of dentistry students about the measures that can prevent the transmission of Hepatitis B, is of great importance. It is necessary that they start clinical practice immunized with the vaccine, are response monitored and well informed about the possible transmission of viral infections in the dental office. Rarely, there have been studies that assess simultaneously the knowledge of dental students about Hepatitis B, their vaccination status and their immunization status. Furthermore, there are no reports of mandatory programs for vaccination together with the analysis of seroconversion in dental schools in Brazil.

\section{Objectives}

This study aims to evaluate knowledge about Hepatitis $B$, the vaccine situation and the status of academic dentists' immunization, and to investigate the possible correlation between the status of immunization, vaccination membership and adherence to the test of seroconversion and associated factors.

\section{Patients and Methods}

\subsection{Study Design}

This was a cross-sectional observational study conducted on students of Dentistry of the UFPI.

\subsection{Study Population}

The sample was of censitary type, composed of students from the Dentistry course of the UFPI, who were from the 3rd to the 9th period, who accepted to participate in the research.

\subsection{Data Collection}

\subsubsection{Stages of the research}

1st step: during the period from 14th to 27th January, 2013, a self-administered form, consisting of 29 closed questions and 3 open-ended questions, containing socioeconomic-demographic information and about knowledge and practice of Hepatitis B control, was provided to the subjects. Before answering the form, the students signed an Informed Consent Form (ICF).

2nd Step: a campaign was conducted among academics of dentistry of UFPI from 28th January to 3rd February, 2013, emphasizing the importance of the study. In this campaign, students were invited to participate in the third stage of the study.

3rd Step: after signing a second ICF, the academics were submitted to blood collection for laboratory evaluation of serological markers. The examination was carried out from to 4th to 8th February 2013, by a nursing technique of the Central Laboratory of Piaui (LACEN/PI). $5 \mathrm{ml}$ of blood was collected by venipuncture, using a syringe (10 $\mathrm{ml}$ ) and disposable hypodermic needle, without anticoagulant.

\subsection{Data Analysis}

The blood was centrifuged to separate the serum used for research of antibodies. The serum samples were tested qualitatively for the serological markers Anti-HBs and total Anti-HBc. For this, we used the enzyme-linked immunosorbent assay test (ELISA) (BIOKIT, Barcelona, Spain), following the manufacturer's instructions.

\subsubsection{Anti-HBs}

Certain parameters for the reading the results:

A-Positive: absorbance/cut-off $\geq 1,0$

B-Negative: absorbance /cut-off $<0,9$

C-Doubtful: 0, $9 \leq$ absorbance /cut-off $<1,0$

\subsubsection{Interpretation of the Results}

Positive results for anti-HBs indicate immune response against HBV infection, immune response to the vaccine or the presence of passively acquired antibodies. To determine if a student had positive results for anti-HBs, only due to prior contact with the virus and not the effect of the vaccine, an anti-HBc test using the ELISA test was used, following the manufacturer's instructions.

\subsubsection{Anti-HBc Total}

Certain parameters for the reading the results: A-Positive: absorbance/cut-off $\leq 1,0$

B-Negative: absorbance/cut-off $>1,1$

C-Doubtful: 1, $0<$ absorbance/cut-off $\leq 1,1$.

\subsubsection{Interpretation of the Results}

Anti-HBc positive result means that the patient has come into contact with the HBV.

After laboratory analysis, the volunteers were classified into three profiles:

Profile 1- Immune by previous contact with the virus (Anti-HBc Total positive and Anti-HBs positive)

Profile 2- Immune by vaccination (Anti-HBc Total negative and Anti-HBs positive).

Profile 3-Individual susceptible (Anti-HBc total negative and Anti-HBs negative). 
Sacchetto MSLdS et al.

\subsubsection{Statistical Analysis}

For analysis of the data, the Stata v.11.0 program was used (Stata Corporation, College Station, TX, USA). The univariate analysis was performed by descriptive statistics through frequencies and percentages. In bivariate analysis, to check the association between qualitative variables, the Pearson's Chi-square test $\left(\chi^{2}\right)$ or FISHER test were employed as relevant and to measure the effect of exposure of variables (immunization status and knowledge about the degree of virulence of HBV) prevalence ratios (PR) were calculated and its respective confidence interval of $95 \%$ was considered statistically significant, $p$ values $\leq 0.05$.

\subsection{Ethical Aspects}

The research followed the standards contained in the Declaration of Helsinki governing research involving human beings and was approved by the Research Ethics Committee of the UFPI (08810412000005214).

\section{Results}

During the study period, 189 students were registered from the course of dentistry of the UFPI, from the 3rd to 9th period. From these candidates, 179 (94.7\%) agreed to participate in the study, 2 were excluded from the study by participating directly in the research and 8 refused to participate. Of the 179 students, 56.4\% were female and their average age was $21.9( \pm 2.3)$.

During clinical care, $99.4 \%$ of the students wore gloves, mask and surgical cap, as protective measures. In table 1 data on students ' knowledge about hepatitis B and the history of the participants and their families in relation to the disease are described.

Students were asked about the ways of transmission of HBV. The result is summarized in Figure 1.

The same process was done in relation to the ways of prevention. The alternatives commonly selected by the students were the use of PPE $(88,2 \%)$, vaccination $(92,7 \%)$ and the practice of safe sex $(62,4 \%)$ and consumption of boiled water or treated (11,8\%).

The responses of the questionnaires relating to questions about the vaccine situation and knowledge of the process of vaccination against HVB are summarized in Table 2 .

\subsection{Laboratorial Step}

Of the 179 students who responded to the form, 159 $(88.82 \%)$ participated in the blood collection. This sample loss was attributed mostly to the fear of the individuals from blood withdrawal. The loss was analysed and it was found by the Pearson's Chi-square test that there was no significant difference between the variables: gender $(\mathrm{P}=$ $0,539)$, age group $(P=0,262)$, period of the course $(P=$
$0,577)$ and thus clinical practice was initiated $(P=0,741)$

Table 1. Students' Knowledge about HVB and HVB Diagnosis in the Family Reported by the Research Participants $(n=179)$

\begin{tabular}{|c|c|}
\hline & No. (\%) \\
\hline \multicolumn{2}{|c|}{ Do you know or have heard of Hepatitis B? } \\
\hline No & $2(1.1)$ \\
\hline Yes & $177(98.9)$ \\
\hline \multicolumn{2}{|c|}{$\begin{array}{l}\text { Do you have or have you been diagnosed } \\
\text { with hepatitis B? }\end{array}$} \\
\hline No & $176(98.3)$ \\
\hline Yes & $03(1.7)$ \\
\hline \multicolumn{2}{|c|}{ Hepatitis B in family history? } \\
\hline No & $132(73.7)$ \\
\hline Yes & $07(3.9)$ \\
\hline I don't know & $40(22.3)$ \\
\hline \multicolumn{2}{|c|}{$\begin{array}{l}\text { Are there risks for people who live with the } \\
\text { virus carrier? }\end{array}$} \\
\hline No & $39(21.8)$ \\
\hline Yes & $120(67.0)$ \\
\hline I don't know & $20(11.2)$ \\
\hline \multicolumn{2}{|c|}{ Is this disease curable? } \\
\hline No & $62(34.6)$ \\
\hline Yes & $82(45.8)$ \\
\hline I don't know & $35(19.6)$ \\
\hline \multicolumn{2}{|c|}{ Is there any vaccine against this disease? } \\
\hline No & $02(1.1)$ \\
\hline Yes & $174(97.2)$ \\
\hline I don't know & $03(1.7)$ \\
\hline \multicolumn{2}{|c|}{ Level of HBV virulence } \\
\hline Low & $16(8.9)$ \\
\hline Medium & $51(28.5)$ \\
\hline High & $104,(58.1)$ \\
\hline Ignored/No answer & $08,(4.5)$ \\
\hline
\end{tabular}

with the existing losses.

As for the serological analysis of anti-HBs, 126 (79.2\%) of the 159 students assessed were positive and 33 (20.8\%) were negative.

In the analysis of total anti-HBc, it was found that only 1 academic was positive, however, this student was antiHBs negative. Thus the profile of the academics regarding protection against HBV was thus distributed:

Profile 1 (immune by previous contact with the virus): $0,6 \%$

Profile 2 (Immune by vaccination): $79.2 \%$

Profile 3 (Individual susceptible): $20.2 \%$ 


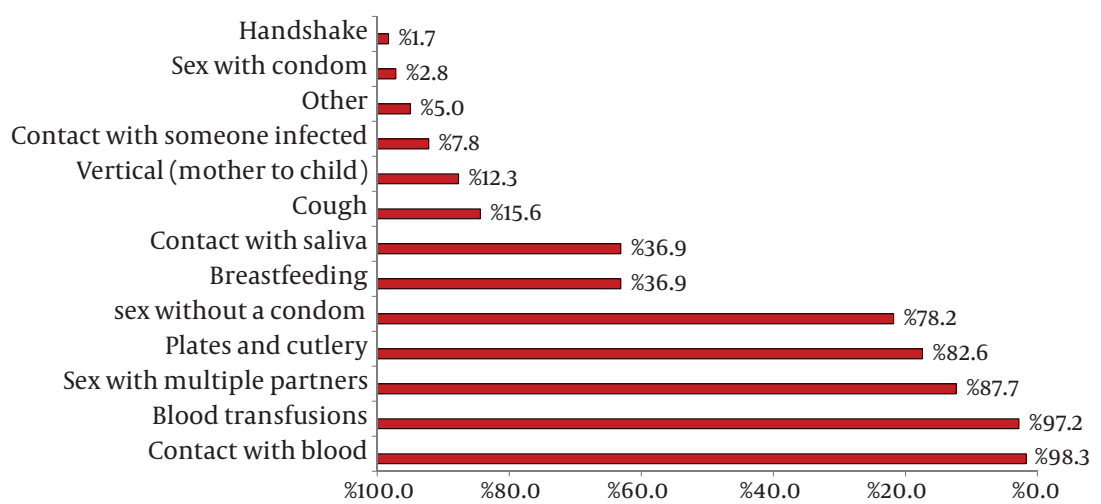

Figure 1. Main ways of Transmission Reported by the Research Participants ( $\mathrm{n}=179$ )

Table 2. Data Concerning Knowledge About Vaccination Against Hepatitis B, the Vaccine Situation and Anti-HBs test Reported by the Research Participants

\begin{tabular}{|c|c|}
\hline & No.(\%) \\
\hline \multicolumn{2}{|c|}{$\begin{array}{l}\text { Are you vaccinated against Hepatitis } B \text { ? (n } \\
=179)\end{array}$} \\
\hline No & $17(9.5)$ \\
\hline Yes & $143(79.9)$ \\
\hline I don't know & $19(10.6)$ \\
\hline \multicolumn{2}{|l|}{ If not why? $(n=36)$} \\
\hline No interest & $02(5.6)$ \\
\hline Forgetfulness & $18(50.0)$ \\
\hline Other & $06(16.7)$ \\
\hline No answer & $10(27.8)$ \\
\hline \multicolumn{2}{|c|}{ Took all doses? $(n=143)$} \\
\hline No & $33(23.1)$ \\
\hline Yes & $98(68.5)$ \\
\hline I don't know & $12(8.4)$ \\
\hline \multicolumn{2}{|c|}{ How many doses did you get? $(n=143)$} \\
\hline 1 dose & $02(1.4)$ \\
\hline 2 doses & $07(4.9)$ \\
\hline 3 doses & $89(62.2)$ \\
\hline No answer/Ignored & $45(31.5)$ \\
\hline \multicolumn{2}{|c|}{ How many doses should be taken? $(n=179)$} \\
\hline 1 dose & $04(2.8)$ \\
\hline 2 doses & $04(2.8)$ \\
\hline 3 doses & $125(87.4)$ \\
\hline 4 doses & $03(2.1)$ \\
\hline No answer/Ignored & $43(4.9)$ \\
\hline
\end{tabular}

How long has it been since the completion of the vaccination schedule? $(n=143)$

$\leq 6$ months
$>6$ months
No answer/Ignored
Did you Know or have heard about Anti-
HBs test? $(\mathbf{n}=\mathbf{1 7 9})$

$13(9.1)$

$85(59.4)$

$45(31.5)$

$\begin{array}{ll}\text { No } & 92(51.4) \\ \text { Yes } & 87(48.6)\end{array}$

If Yes, where did you obtain this informa-

tion $(\mathbf{n}=\mathbf{8 7})$

$\begin{array}{ll}\text { University classes } & 70(80.5) \\ \text { In articles, books etc. } & 18(20.7) \\ \text { Internet } & 11(12.6) \\ \text { Other } & 01(1.2) \\ \text { Specialized establishments } & 07(8.0)\end{array}$

Have you had the Anti-HBs test $?(n=179)$

$\begin{array}{ll}\text { No } & 169(94.4) \\ \text { Yes } & 10(5.6) \\ \text { If not why? }(\mathbf{n}=\mathbf{1 6 9}) & \\ \text { I don't know the test } & 81(47.9) \\ \text { Forgetfulness } & 33(19.5) \\ \text { I don't have no interest } & 02(1.2) \\ \text { Other } & 45(26.6) \\ \text { No answer/Ignored } & 08(4.7)\end{array}$

If Yes, how long after the last dose of vaccination? $(\mathbf{n}=\mathbf{1 0})$

\begin{tabular}{ll}
$\geq 6$ months & $02(20.0)$ \\
$<6$ months & $08(80.0)$ \\
\hline
\end{tabular}

\subsection{Bivariate Analysis}

There was no statistically significant association between the Anti-HBs and the variables analyzed (Table 3). 
Sacchetto MSLdS et al.

Table 3. Relationship Between Gender, Age, Number of Doses and Time of Completion of the Vaccination Scheme with the Immunization Status

\begin{tabular}{|c|c|c|c|c|c|}
\hline Variables & & Hbs & Total, No. (\%) & $\mathbf{R P}^{\mathrm{a}}\left(\mathrm{CI}^{\mathrm{a}} \mathbf{9 5} \%\right)$ & Pvalue $^{b}$ \\
\hline & Positive No. (\%) & Negative No. (\%) & & & \\
\hline Gender & & & & & 0.888 \\
\hline Female & $67(78.8)$ & $18(21.2)$ & $85(100.0)$ & $\operatorname{Ref}^{\mathrm{a}}$ & \\
\hline Male & $59(79.7)$ & $15(20.3)$ & 74100.0 & $0.96(0.48-1.90)$ & \\
\hline Age, $y$ & & & & & 0,320 \\
\hline $18-20$ & $31(81.6)$ & $07(18.4)$ & 38100.0 & ref. & \\
\hline $21-23$ & $75(81.5)$ & $17(18.5)$ & 92100.0 & $0.77(0.39-1.53)$ & \\
\hline$\geq 24$ & $20(69.0)$ & $09(31.0)$ & 29100.0 & $1.68(0.78-3.61)$ & \\
\hline Number of doses & & & & & $0.122^{\mathrm{C}}$ \\
\hline 1 & $01(50.0)$ & $01(50.0)$ & 02100.0 & ref. & \\
\hline 2 & $05(71.4)$ & $02(28.6)$ & 07100.0 & $2.13(0.47-9.61)$ & \\
\hline 3 & $70(87.5)$ & $10(12.5)$ & 80100.0 & $0.37(0.10-1.36)$ & \\
\hline $\begin{array}{l}\text { Time of vaccination } \\
\text { conclusion, mo }\end{array}$ & & & & & $0.444^{\mathrm{C}}$ \\
\hline$\leq 6$ & $11(91.7)$ & $01(8.3)$ & 12100.0 & ref. & \\
\hline$>6$ & $65(84.4)$ & $12(15.6)$ & 77100.0 & $1.87(0.24-14.38)$ & \\
\hline
\end{tabular}

There was no statistically significant result regarding the relationship between gender $(P=0,542)$, period of the course $(P=0,616)$, history of hepatitis $B$ in the family, history of occupational accident $(P=0,211)$ and the knowledge of immunization status. Also, there was no meaningful result on the relationship between gender $(\mathrm{P}$ $=0,818)$, period of the course $(P=0,492)$, history of hepatitis $\mathrm{B}$ in the family $(\mathrm{P}=0,615)$, history of occupational accident $(\mathrm{P}=0,981)$ and the account of having completed the vaccination scheme.

\section{Discussion}

Dental students should know the ways of transmission and prevention against HBV, since the proper attitude against the disease is the primary way, which is to prevent its spread $(16,17)$. The results of this study indicate that the students of the dentistry course of UFPI who attend the 3rd to 9 th periods, parts of the course in which there is clinical practice, do not demonstrate safety regarding transmission of HVB.

In this study, few scholars considered vertical transmission as a form of contagion, and most of them pointed to the common use of plates and cutlery as the transmission medium. These results suggest that students confuse the contamination means of various types of hepatitis. In addition, some surveyed participants thought that coughing transmits Hepatitis B, and many of them demonstrated that they did not know HBV virus as highly virulent. This study is consistent with a survey conducted in Iran (16) and India (17). Already, a study of dental students in Taiwan (18) revealed that they are knowledgeable about the disease and its means of transmission.

It was possible to observe a contradictory behavior between the academics, since most cited the vaccine as a way of prevention, but little more than half of the students reported having completed the vaccination schedule. The low adhesion to the vaccine program is not justified, considering that, in Brazil, vaccination is free of charge and released to health care students (19). These results resemble those pointed out by Sing A et al. (2010) (19) and Acosta-Gió AE et al. (2008) (20), but differ from other results $(7,9,18,21-23)$ in which the percentage of completion of the vaccination scheme varies from 73 , $8 \%$ to $97 \%$.

Seroconversion is the appearance of antibodies against HBV in the blood in an amount sufficient to ensure immunity $(11,24-28)$. In this study, less than half of the students were aware of the seroconversion test and only $5.6 \%$ performed the test. This result does not resemble that reported by other researches $(7,9,22)$ where the percentage of seroconversion analysis ranged from $14.8 \%$ to $47.88 \%$.

The attitude of the dentist towards completion of the immunization schedule and to check if he is immunized may be related to other characteristics. In the survey among dentists in Belo Horizonte (Brazil), women and professionals who had HVB in their family history, completed the vaccination schedule most frequently (22). In the present study, these variables did not influence the 
behavior of students, perhaps for the small amount of sample.

In the present study, there was no significant relationship between the course period and the knowledge of immunization status and/or the full vaccination, revealing the need for continuing education, a result also found in a study with Iranian academics of dentistry (9). However, these results do not resemble those of a survey with students of Dentistry of Croatia, in which it was evidenced that the attitudes and knowledge regarding HBV improve in the course of graduation (29).

In this research, of the 159 academics who accepted to participate in the laboratory step, only 1 had a positive outcome for total Anti-HBc and this student was negative for Anti-HBs, probably due to the decreased concentration of Anti-HBs to levels undetectable by serological tests over the years (4). This result is similar to those of a survey conducted at the University of Bahia (Brazil) (11) and a study conducted at the Mato Grosso (Brazil) (30).

Regarding the result of Anti-HBs, 79.2\% of the students were considered immune by vaccination response, and 20.2\% were considered susceptible. However, when the analysis was performed, only among students who reported having completed the vaccination, the percentage of people unprotected decreased to $12.5 \%$, showing the importance of completing the scheme. In the literature, the percentage of healthcare professionals who remain unprotected after 3 doses of vaccine, ranged from $5.85 \%$ to $20.9 \%(7,24,30,31)$.

This difference in seroprotection is probably due to several factors that supposedly can influence the concentration of anti-HBs. Studies have shown that age (7, 9, $32)$ and the time of vaccination $(7,9,13,24,33)$ negatively influence the amount of antibodies after completion of the immunization schedule, the number of doses taken increases the concentration of anti-HBs (32) and gender has no influence on seroconversion $(7,9,30)$. In this study none of the variables analyzed, influence the concentration of anti-HBs.

The time of the vaccine protection against Hepatitis B continues to be widely discussed (34). This research has some limitations such as the fact that the sample size was small and there was a lack of confirmation of the reports, because students did not have a vaccination card.

In conclusion, the results of this study demonstrated that dental students were unsure about the ways of infection and prevention of Hepatitis B, and a large part did not complete the vaccination before starting clinical practice and a small percentage performed this test. Serological analysis confirmed the literature and revealed unprotected pupils, even after completion of the vaccination. It is suggested that during the graduation, education campaigns on the disease must take place and the delivery of the Anti-HBs test results must be a pre-requisite for the onset of clinical practice.

\section{Acknowledgements}

We acknowledge the biochemists Fabiano Vieira da Silva and Alceu Ribeiro de Sousa for having contributed in the analysis of serum samples.

\section{Authors' Contribution}

Sacchetto SLS participated in the development of the project, participated in the data collection and drafted the manuscript; Barros SSLV idealized and oversaw the research, participated in the development of the project and made the critical review of important intellectual content; Araripe TA e Silva AM reviewed the literature and were responsible for data collection, Faustino SKM oversaw the laboratory analysis of blood samples collected and interpreted the results and Silva JMN performed the statistical analysis.

\section{Financial Disclosure}

Authors declare they have no financial disclosure.

\section{Funding Support}

This study had no financial and material support.

\section{References}

1. Karimi M, Raee A, Baghianimoghadam B, Fallahzadeh MH. Vaccine-Induced Anti-HBs Level in 5-6 Year-Old Malnourished Children. Hepat Mon. 2013;13(2)

2. Alavian SM, Mahboobi N, Savadrudbari MM, Azar PS, Daneshvar S Iranian dental students' knowledge of hepatitis B virus infection and its control practices. J Dent Educ. 2011;75(12):1627-34.

3. Damme PV, Herck KV. A review of the long-term protection after hepatitis A and B vaccination. Travel Med Infect Dis. 2007;5(2):7984.

4. Ministério da Saúde Secretaria de Vigilância em Saúde Departamento de Vigilância Epidemiológica. Hepatites virais: o Brasil está atento. 3 ed. Brasília Série B. :Textos Básicos de Saúde; 2008.

5. Tengan FM, Araújo ESA. Epidemiologia da Hepatite B e D e seu impacto no Sistema de Saúde. In: Sociedade Brasileira de Infectologia (SBI). I Consenso da Sociedade Brasileira de Infectologia para Diagnóstico e Manuseio da Hepatite B (e Delta). Braz J Infect Dis. 2006(suppl.10):6-10.

6. Dehghani SM, Taghavi SA, Geramizadeh B, Nikeghbalian S, Derakhshan N, Malekpour A, et al. Hepatitis B recurrence after liver transplantation: a single center experiences and review the literature. Hepat Mon. 2013;13(1)

7. Alavian SM, Izadi M, Zare AA, Lankarani MM, Assari S, Vardi MM Survey of the level of anti-HBs antibody titer in vaccinated Iranian general dentists. Spec Care Dentist. 2008;28(6):265-70.

8. Burnett RJ, Kramvis A, Dochez C, Meheus A. An update after 16 years of hepatitis B vaccination in South Africa. Vaccine. 2012;30 Suppl 3:C45-51.

9. Alavian SM, Mahboobi N. Anti-HBs antibody status and some of its associated factors in dental health care workers in Tehran University of Medical Sciences: Anti-HBs Ab and associated factors in dental society. Hepat Mon. 2011;11(2):99-102.

10. Araujo MW, Andreana S. Risk and prevention of transmission of infectious diseases in dentistry. Quintessence Int (Berlin, Germany: 1985). 2002;33(5):376-82.

11. Carvalho P, Schinoni MI, Andrade J, Vasconcelos Rego MA Marques P, Meyer R, et al. Hepatitis B virus prevalence and vaccination response in health care workers and students at the 
Federal University of Bahia, Brazil. Ann Hepatol. 2012;11(3):330-7.

12. Ammon A, Reichart PA, Pauli G, Petersen LR. Hepatitis B and C among Berlin dental personnel: incidence, risk factors, and effectiveness of barrier prevention measures. Epidemiol Infect. 2000;125(2):407-13.

13. Livramento A, Cordova CMM, Scaraveli NG, Tonial GC, Spada C, Treitinger A. Anti-HBs levels among children and adolescents with complete immunization schedule against hepatitis B virus. A cross-sectional study in Blumenau, State of Santa Catarina, Brazil, 2007-2008. Rev Soc Bras Med Tro. 2011;44(4):412-5.

14. Abe M, Akbar SM, Onji M. Zinc and hepatitis B virus vaccination. Hepatol Res. 2006;35(1):1-2.

15. Wang C, Tang J, Song W, Lobashevsky E, Wilson CM, Kaslow RA HLA and cytokine gene polymorphisms are independently associated with responses to hepatitis B vaccination. Hepatology. 2004;39(4):978-88.

16. Mansour-Ghanaei R, Joukar F, Souti F, Atrkar-Roushan Z. Knowledge and attitude of medical science students toward hepatitis B and C infections. Int J Clin Exp Med. 2013;6(3):197-205.

17. Maroof KA, Bansal R, Parashar P, Sartaj A. Do the medical, denta and nursing students of firstyear know about hepatits B? A study from a university of North India. J Pak Med Assoc. 2012;62(1):25-7.

18. Hu SW, Lai HR, Liao PH. Comparing dental students' knowledge of and attitudes toward hepatitis B virus-, hepatitis C virus-, and HIV-infected patients in Taiwan. AIDS Patient Care STDS. 2004;18(10):587-93.

19. Singh A, Purohit BM, Bhambal A, Saxena S, Gupta A. Knowledge, attitudes, and practice regarding infection control measures among dental students in Central India. J Dent Educ. 2011;75(3):421-7.

20. Acosta-Gio AE, Borges-Yanez SA, Flores M, Herrera A, Jeronimo J, Martinez $\mathrm{M}$, et al. Infection control attitudes and perceptions among dental students in Latin America: implications for dental education. Int Dent J. 2008;58(4):187-93.

21. Ferreira RC, Guimarães ALS, Pereira RD, Andrade RM, Xavier RP Martins AMEBL. Hepatitis B vaccination and associated factors among dentists. Revista Brasileira de Epidemiologia. 2012;15(2):31523.

22. Resende VL, Abreu MH, Paiva SM, Teixeira R, Pordeus IA. Concerns regarding hepatitis $B$ vaccination and post-vaccination test among Brazilian dentists. Virol J. 2010;7:154.

23. Rhodes A, Aw TC, Allen C, Ridout M. Immunisation status of den- tal practice staff in Kent. Br Dent J. 2008;205(10):E20.

24. Elisbão MCM, Baldy JLS, Bonametti AM, Reiche EMV, Morimoto $\mathrm{HK}$, Pontello R, et al. Intradermal vaccination of adults with three low doses $(2 \mu \mathrm{g})$ of recombinant hepatitis B vaccine. II. Persistence of immunity and induction of immunologic memory. Mem I Oswaldo Cruz. 2003;98:1109-13.

25. Garcia LP, Blank VLG, Blank N. Aderência a medidas de proteção individual contra a hepatite $B$ entre cirurgiões-dentistas e auxiliares de consultório dentário. Revista Brasileira de Epidemiologia. 2007; 10:525-35.

26. Khouri El, Santos VA. Hepatitis B: epidemiological, immunologi$\mathrm{cal}$, and serological considerations emphasizing mutation. Revista do Hospital das Clínicas. 2004;59:216-24.

27. Mahboobi N, Agha-Hosseini F, Safari S, Lavanchy D, Alavian SM. Hepatitis B virus infection in dentistry: a forgotten topic. J Viral Hepat. 2010;17(5):307-16.

28. Vieira TB, Pereira R, Santos KF, leal DBR. Soroconversão após a vacinação para Hepatite B em acadêmicos da área da saúde. Disc Scientia. Série: Ciências da Saúde . 2006;7(1):13-21.

29. Brailo V, Pelivan I, Škari i J, Vuleti M, Dul i N, Cerjan-Letica G. Treating Patients with HIV and Hepatitis B and C Infections: Croatian Dental Students' Knowledge, Attitudes, and Risk Perceptions. J Dent Educ. 2011;75(8):1115-26.

30. Melo LV, da Silva MA, Calcada Cde O, Cavalcante SR, Souto FJ. Hepatitis B virus markers among teenagers in the Araguaia region, Central Brazil: assessment of prevalence and vaccination coverage. Vaccine. 2011;29(32):5290-3.

31. Batista SM, Andreasi MS, Borges AM, Lindenberg AS, Silva AL, Fernandes TD, et al. Seropositivity for hepatitis B virus, vaccination coverage, and vaccine response in dentists from Campo Grande, Mato Grosso do Sul, Brazil. Mem Inst Oswaldo Cruz. 2006;101(3):263-7.

32. Lasemi E, Haddadpour N, Navi F, Rakhshan A, Rakhshan V. Rate of acquired immunity in dental students after hepatitis B vaccination. Dent res j. 2011;8(3):128.

33. Sukriti, Pati NT, Sethi A, Agrawal K, Kumar GT, Kumar M, et al. Low levels of awareness, vaccine coverage, and the need for boosters among health care workers in tertiary care hospitals in India. $J$ Gastroenterol Hepatol. 2008;23(11):1710-5.

34. Su FH, Chu FY, Bai CH, Lin YS, Hsueh YM, Sung FC, et al. Efficacy of hepatitis B vaccine boosters among neonatally vaccinated university freshmen in Taiwan. J Hepatol. 2013;58(4):684-9. 